\title{
PENGARUH TINGKAT SALINITAS MEDIA PEMELIHARAAN TERHADAP KUALITAS DAGING IKAN MAS (Cyprinus carpio)
}

\author{
Lies Setijaningsih"), Kunto Purnomo, "dan Chairulwan Umar")
}

\begin{abstract}
ABSTRAK
Dalam rangka meningkatkan nilai tambah pada ikan mas, telah dilakukan penelitian untuk mengetahui pengaruh tingkat salinitas terhadap kualitas daging ikan mas. Tingkat salinitas yang dipakai adalah 0, 6, 8, dan $10 \mathrm{ppt}$. Ikan yang digunakan ukuran $100 \mathrm{~g}$, berasal dari kolam air deras dan keramba jaring apung. Kualitas daging ikan mas ditentukan dengan menggunakan parameter tekstur daging dan rasa. Rancangan percobaan yang digunakan adalah rancangan acak lengkap.

Hasil penelitian menunjukkan bahwa perlakuan cara asal budi daya, lama pemeliharaan, dan tingkat salinitas berpengaruh nyata terhadap kualitas daging ikan. Ikan yang berasal dari hasil budi daya kolam air deras mempunyai tekstur daging yang lebih baik. Ikan yang berasal dari kolam air deras menunjukkan tekstur terting $0,72 \mathrm{~kg} / \mathrm{mm}$ pada hari ke-12 dengan salinitas 8 ppt dan ikan yang berasal dari keramba jaring apung menunjukkan tekstur tertinggi $0,661 \mathrm{~kg} / \mathrm{mm}$ pada hari ke-16 dengan salinitas 10 ppt. Salinitas sangat nyata berpengaruh terhadap tekstur dan rasa seperti ditunjukkan oleh kandungan asam amino histidin dan prolin daging ikan mas.
\end{abstract}

ABSTRACT: Influence of salinity levels of culture media on meat quality of common carp. By: Lies Setijaningsih, Chairulwan Umar, dan Kunto Purnomo.

In order to increase value added of common carp, an experiment on the influence of salinity levels of culture media on the texture of common carp meat has been conducted. The salinity levels of culture media used were $0,6,8$, and 10 ppt. One hundred gram of fish harvested from floating cage and running water systems were used. The meat quality was measured from the meat taste and its elasticity. The experimental design applied was completely randomized design.

The result showed that the culture type, culture period, and water salinity levels were significanly affect the quality of carp meat. The meat texture of fish culture in the running water cultured system, i.e. $0.72 \mathrm{~kg} / \mathrm{mm}$ elasticyty, was reached after 12 days rearing at 8 ppt of salinity and the best texture of the fish from floating cage cultured system i.e. $0.61 \mathrm{~kg} / \mathrm{mm}$ elasticity was reached after 16 days rearing at 10 ppt of salinity. Water salinity was significantly affect the texture and taste of carp meat which can be seen on the higher content of histidin and prolin.

KEYWORDS: salinity, texture, taste, common carp

\section{PENDAHULUAN}

Budi daya ikan mas dalam keramba jaring apung maupun kolam air deras sampai saat ini masih mengutamakan produksinya daripada segi kualitas dagingnya. Mutu ikan yang baik ditentukan oleh kualitas dagingnya. Kualitas daging ikan dipengaruhi oleh aspek internal dan eksternal. Aspek internal merupakan sifat yang sulit dikontrol seperti keturunan, umur, jenis kelamin, dan aktivitas fisiologi, sedangkan aspek eksternal dipengaruhi sifat fisik dan kimiawi lingkungan perairan sebagai media hidupnya (Halver, 1972). Salah satu sifat lingkungan yang dapat mempengaruhi aktivitas fisiologi ikan adalah salinitas. Salinitas adalah total konsentrasi garam-garam yang terionisasi atau terlarut dalam air yang disetarakan dengan garam natrium klorida (Knut Schmidt \& Nielsen, 1988). Ikan air tawar yang dipelihara pada media salinitas yang lebih tinggi, di mana konsentrasi garam dalam tubuhnya lebih kecil daripada konsentrasi garam medium, cenderung mengekskresikan air lewat selaput keluar dari tubuh untuk mencapai homeostatis (Nybakken, 1988). Perubahan lingkungan dari air tawar ke lingkungan yang bersalinitas membutuhkan perubahan dalam proses osmoregulasi. Dalam osmoregulasi dalam tubuh ikan diproduksi senyawa yang menyebabkan isotonik dengan lingkungan antara lain asam amino bebas, yang sering disebut dengan depression freezing point. Pengaruh konsentrasi salinitas terhadap kualitas daging ikan air tawar berkorelasi positif dengan tekstur dagingnya. Selain itu dapat meningkatkan nilai organoleptik pada tekstur, rasa, dan bau yang dibuktikan pada percobaan yang dilakukan pada ikan nila merah (Anggawati et al., 1991), dan pada ikan gurami (Setijaningsih, 1999).

Peneliti pada Balai Penelitian Perikanan Air Tawar 
Informasi daya adaptasi ikan mas pada media bersalinitas masih sangat terbatas. Upaya untuk memperbaiki kualitas daging ikan mas melalui pendekatan lingkungan bersalinitas pada tingkat salinitas yang berbeda perlu dicoba. Ikan mas mudah menyesuaikan diri terhadap perubahan suhu, keadaan makanan, dan lingkungan tempat hidupnya (Ardiwinata, 1981). Untuk memberikan nilai tambah pada ikan mas perlu dicoba daya tahannya terhadap berbagai tingkat salinitas. Dalam percobaan ini diuji pengaruh tingkat salinitas terhadap kualitas daging ikan mas.

\section{BAHAN DAN METODE}

\section{Penelitian Pendahuluan}

Penelitian ini dilaksanakan di Laboratorium Nutrisi Balai Penelitian Perikanan Air Tawar Sukamandi selama enam minggu. Empat minggu digunakan untuk penelitian pendahuluan dengan tujuan untuk mengetahui tingkat salinitas yang dapat ditolerir oleh ikan mas untuk hidup yaitu 0, 5, 10, dan 15 ppt. Wadah yang digunakan adalah akuarium berkapasitas $140 \mathrm{~L}$ yang dilengkapi dengan sistem aerasi dari suatu portable blower yang didistribusikan melalui selang plastik. Ikan mas diperoleh dari Balai Benih Ikan di Wanayasa, Purwakarta dengan bobot rata-rata 100 g/ekor. Bagian atas setiap wadah percobaan ditutup dengan jaring untuk mencegah ikan meloncat ke luar.

Periakuan pada penelitian pendahuluan adalah 3 kombinasi acak lengkap pola faktorial dari 2 faktor. Faktor pertama adalah ukuran ikan $100 \mathrm{~g}$ dengan kepadatan 10 ekor/wadah dan faktor kedua adalah air berbeda salinitas yang terdiri atas 4 taraf, yaitu 0 , 5, 10, dan 15 ppt. Setiap kombinasi diulang tiga kali.

\section{Penelitian Lanjutan}

Penelitian selanjutnya adalah untuk mengetahui kadar salinitas yang dapat meningkatkan kualitas daging ikan mas. Perlakuan yang diteliti adalah 24 kombinasi faktorial dari tiga faktor. Faktor pertama adalah media salinitas yang mengacu pada hasil penelitian pendahuluan yang terdiri atas tiga taraf yaitu 6,8 , dan 10 ppt. Faktor ke dua adalah jenis asal habi- tat yang terdiri atas dua taraf, yaitu keramba jaring apung dan kolam air deras. Setiap kombinasi diulang tiga kali. Faktor ke tiga yaitu lama pemeliharaan 4, 8 , 12, dan 16 hari.

Pakan yang diberikan adalah pakan komersial dalam bentuk pelet dengan frekuensi pemberian tiga kali sehari. Banyaknya pakan yang diberikan yaitu sekenyangnya (satiation)

Sisa pakan dan kotoran disifon setiap hari sebelum pemberian pakan pada pagi hari, kemudian dilakukan penambahan air sebanyak yang keluar dari penyifonan. Kondisi lingkungan terutama salinitas tetap diupayakan sesuai dengan perlakuan.

Analisis asam amino dilakukan pada awal dan akhir penelitian, sedangkan karkas dan organoleptik dikerjakan setiap empat hari. Pelaksanaan penilaian organoleptik melalui panel yang bertindak sebagai instrumen. Panel terlatih sebanyak 3-5 orang. sedangkan panel tidak terlatih terdiri atas 15-25 orang (Soekarto et al., 1985). Dalam pelaksanaan penilaian organoleptik digunakan lembar penilaian dengan uji skoring. Pengamatan parameter tekstur daging ikan mas menggunakan metode pengukuran objektif dengan alat ukur teksturometer instron tipe Warner Bratzler meat shearyang akan menghasilkan grafik dengan satu titik puncak "nilai kekerasan" dengan satuan $\mathrm{kg}$, dan kekenyalan dengan satuan $\mathrm{mm}$. Hasil bagi dari nilai kekerasan $(\mathrm{kg})$ dan kekenyalan ( $\mathrm{mm}$ ) merupakan nilai tekstur daging ikan. Pengamatan tekstur dilakukan setiap empat hari sekali. Analisis data dilakukan dengan uji sidik ragam (anova) untuk mengetahui pengaruh perlakuan

\section{HASIL DAN BAHASAN}

\section{Hasil Penelitian Pendahuluan}

Dari hasil pengamatan selama percobaan pendahuluan diperoleh data laju sintasan ikan uji yang berasal dari kolam air deras dan keramba jaring apung pada media salinitas 5 dan 10 ppt yaitu berkisar antara $97-100 \%$ (rata-rata 98,6\% dan 98,7\%). Pada salinitas 15 ppt memperlihatkan mortalitas yang tinggi dan hanya bertahan selama 6 jam (Tabel 1)

Tabel 1. Rata-rata sintasan dari ikan mas pada salinitas yang berbeda selama 30 hari

Table 1. Average survival rate of common carp at different salinities during 30 days

\begin{tabular}{ccc}
\hline \multirow{2}{*}{$\begin{array}{c}\text { Media salinitas } \\
\text { Salinity of media }\end{array}$} & \multicolumn{2}{c}{$\begin{array}{c}\text { Sintasan } \\
\text { Survival rate (\%) }\end{array}$} \\
\cline { 2 - 3 } & $\begin{array}{c}\text { Kolam air deras } \\
\text { Running water }\end{array}$ & $\begin{array}{c}\text { Keramba jaring apung } \\
\text { Floating net cage }\end{array}$ \\
\hline 0 & 100.0 & 100.0 \\
5 & 97.9 & 98.2 \\
10 & 97.8 & 97.9 \\
\hline
\end{tabular}




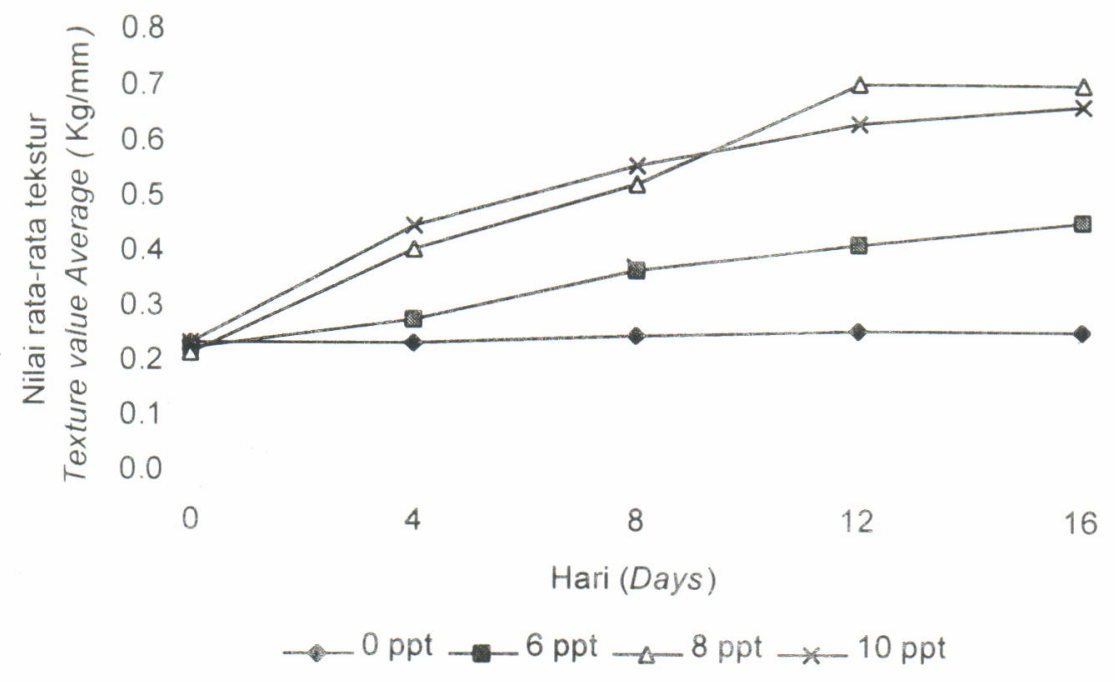

Gambar 1. Nilai rata-rata tekstur daging ikan mas $(\mathrm{kg} / \mathrm{mm})$ asal kolam air deras

Figure 1. Average value of texture of common carp meal $(\mathrm{kg} / \mathrm{mm})$ originated from running water

\section{Hasil Penelitian Lanjutan}

Hasil analisis statistik menunjukkan bahwa perlakuan cara budi daya kolam air deras dan keramba jaring apung, lama adaptasi, pemeliharaaan, dan tingkat salinitas berpengaruh nyata terhadap kualitas daging ikan mas, yang ditunjukkan dengan adanya interaksi antara ketiga faktor perlakuan tersebut.

Ikan mas yang berasal dari kolam air deras, menunjukkan tekstur daging tertinggi pada hari ke-12 dengan salinitas 8 ppt (Gambar 1). Untuk ikan mas yang berasal dari keramba jaring apung tekstur daging tertinggi diperoleh pada hari ke-16 dengan salinitas 10 ppt (Gambar 2). Semua perlakuan salinitas menunjukkan tekstur tertinggi secara nyata dibandingkan dengan kontrol $(p<0,05)$.

Perubahan tekstur daging ikan uji diduga dipengaruhi tidak hanya oleh faktor konsentrasi dan salinitas serta lamanya adaptasi, tetapi juga oleh faktor parameter lingkungan pemeliharaan, yaitu tersedianya organisme makanan dan adanya zatzat seperti oksigen terlarut, karbon dioksida, amonia, nitrat, dan ion hidrogen (Boyd \& Linkoppler, 1979). Selain itu media salinitas mempengaruhi kondisi in.

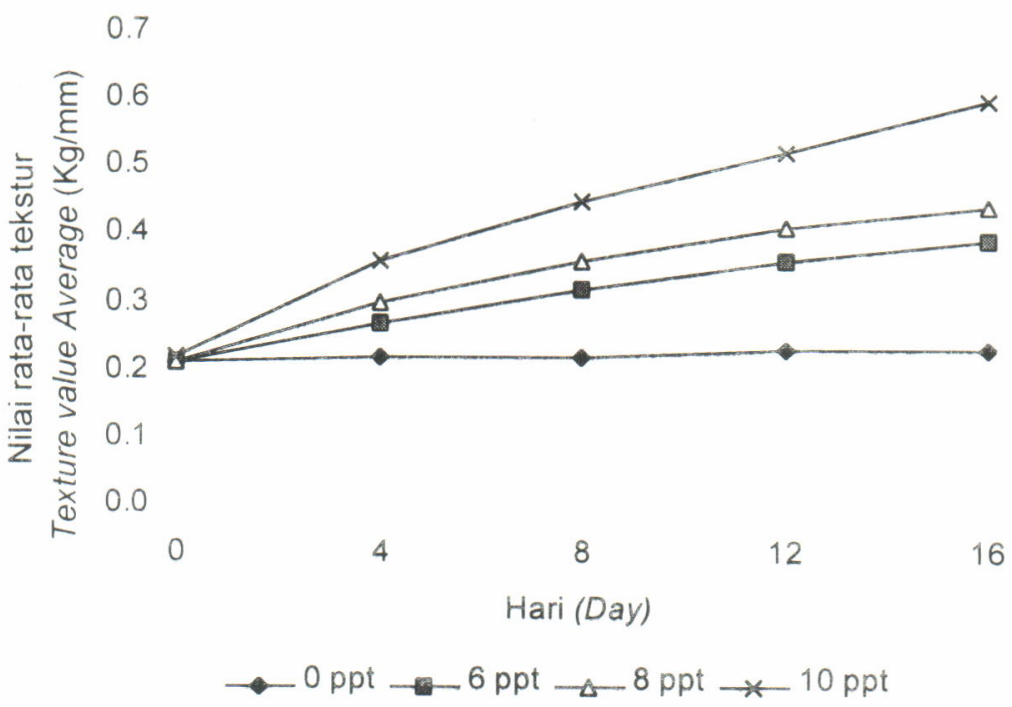

Gambar 2. Nilai rata-rat tekstur daging ikan mas $(\mathrm{kg} / \mathrm{mm})$ asal keramba jaring apung

Figure 2. Average value of texture of common carp meat $(\mathrm{kg} / \mathrm{mm})$ originated from floating cage 
Tabel 2. Kadar protein (\%) daging ikan mas *

Table 2. Protein content (\%) of common carp

\begin{tabular}{|c|c|c|c|c|c|}
\hline \multirow{2}{*}{$\begin{array}{l}\text { Asal ikan } \\
\text { Fish origin }\end{array}$} & \multirow{2}{*}{$\begin{array}{l}\text { Hari } \\
\text { day }\end{array}$} & \multicolumn{4}{|c|}{ Salinitas / Salinity (ppt) } \\
\hline & & 0 & 6 & 8 & 10 \\
\hline & & 14.00 & 14.26 & 15.16 & 15.21 \\
\hline Kolam air deras & 8 & 14.28 & 14.42 & 15.36 & 15.41 \\
\hline \multirow[t]{3}{*}{ Running water } & 12 & 14.31 & 15.53 & $16.27^{\star}$ & 15.89 \\
\hline & 16 & 14.31 & 15.54 & $16.27^{\star}$ & 16.27 \\
\hline & 4 & 12.07 & 14.78 & 14.97 & 15.00 \\
\hline Keramba jaring apung & 8 & 12.07 & 14.83 & 15.01 & 15.52 \\
\hline \multirow[t]{2}{*}{ Floating net cage } & 12 & 12.09 & 14.82 & 15.46 & 15.84 \\
\hline & 16 & 12.09 & 14.89 & 15.78 & $15.89^{*}$ \\
\hline
\end{tabular}

*) rata-rata protein basah dari 3 ulangan (wet basis, mean of 3 replicates)

ternal ikan dengan tekanan osmotik dan konsentrasi cairan tubuh merupakan salah satu faktor yang dipengaruhi dan berdampak terhadap elastisitas daging (Halver, 1972). Faktor tersebut berlaku sama pada ikan air tawar lainnya seperti ikan nila yang diberok dalam air laut selama dua minggu diperoleh tekstur daging yang lebih baik dibandingkan dengan empat minggu (Anggawati et al., 1991). Pada ikan gurami tekstur tertinggi diperoleh setelah diadaptasikan selama delapan hari pada salinitas 8 ppt (Setijaningsih, 1999).

Perbedaan sistem budi daya juga memberikan pengaruh yang nyata pada pencapaian homeostatis. Ikan yang dipelihara di kolam air deras, aktivitas fisik yang dilakukannya lebih intensif di mana komposisi jaringan otot berkembang lebih banyak, dengan akibatnya akan mendominasi komposisi jaringan penyusun daging ikan sehingga tekstur daging ikan lebih kompak.

Hal ini sejalan dengan hasil penelitian Tajerin et al. (1997), yang menyatakan bahwa ikan mas yang dipelihara di kolam air deras lebih baik tekstur dagingnya dibandingkan dengan ikan mas yang dipelihara di kolam air mengalir dan air tenang.

\section{Kandungan Protein}

Protein berperanan dalam menentukan kualitas tekstur daging ikan. Protein berfungsi dalam memperbaiki dan membentuk jaringan (daging ikan) (National Research Council,1977). Jenis protein yang berfungsi sebagai pembentuk jaringan ikat, yang tidak larut dalam air dan larutan garam yaitu protein stroma. Suzuki (1981) menyatakan bahwa kelompok protein stroma juga disebut skleroprotein dengan komponen yang terdiri atas kolagen dan elastin, letaknya pada miokomata dan membran sel yang berfungsi sebagai jaringan ikat.
Jenis protein ini pada media salinitas berperan dalam peningkatan tekstur melalui penggumpalan dan pembentukan jaringan pengikat. Semakin tinggi persentase protein yang terdapat pada daging semakin berkorelasi positif dengan tekstur daging ikan. Berdasarkan data pada Tabel 2 dapat dilihat bahwa perbedaan lamanya beradaptasi pada media salinitas menunjukkan kadar protein ikan uji pada akhir penelitian berbeda. Ikan yang berasal dari keramba jaring apung mempunyai kadar protein sebesar $15,89 \%$, sedangkan kadar protein ikan yang berasal dari kolam air deras adalah 16,27\%. Kadar protein ikan asal kolam air deras yang diadaptasi di salinitas 8 ppt pada hari ke-12 dan ke-16 adalah sama, sehingga dari segi efisiensi baik secara teknis maupun secara ekonomis dipilih bahwa adaptasi pada hari ke12 dengan salinitas $8 \mathrm{ppt}$ adalah yang optimum.

\section{Organoleptik Rasa}

Hasil uji organoleptik rasa ikan mas menunjukkan bahwa pada perbedaan tingkat salinitas memberikan rasa yang berbeda pada ikan asal kolam air deras maupun ikan asal keramba jaring apung (Gambar 3). Perbedaan tingkat salinitas, dapat memberikan pengaruh pada kemampuan ikan dari lingkungannya (Lovell \& Sackey, 1973).

Rasa yang disukai panelis tampaknya paralel dengan semakin lamanya ikan dipelihara pada media salinitas. Skor uji organoleptik rasa dari panelis untuk ikan asal kolam air deras dan ikan asal keramba jaring apung tidak berbeda nyata. Terdapat kecenderungan pada panelis tidak bisa membedakan rasa ikan yang berasal dari kolam air deras dan ikan asal keramba jaring apung yang dipelihara pada media salinitas.

Kandungan beberapa asam amino bebas, seperti prolin dan histidin dapat memberikan kelezatan rasa yang enak pada daging ikan (Ding et al.,1989). Hasil 


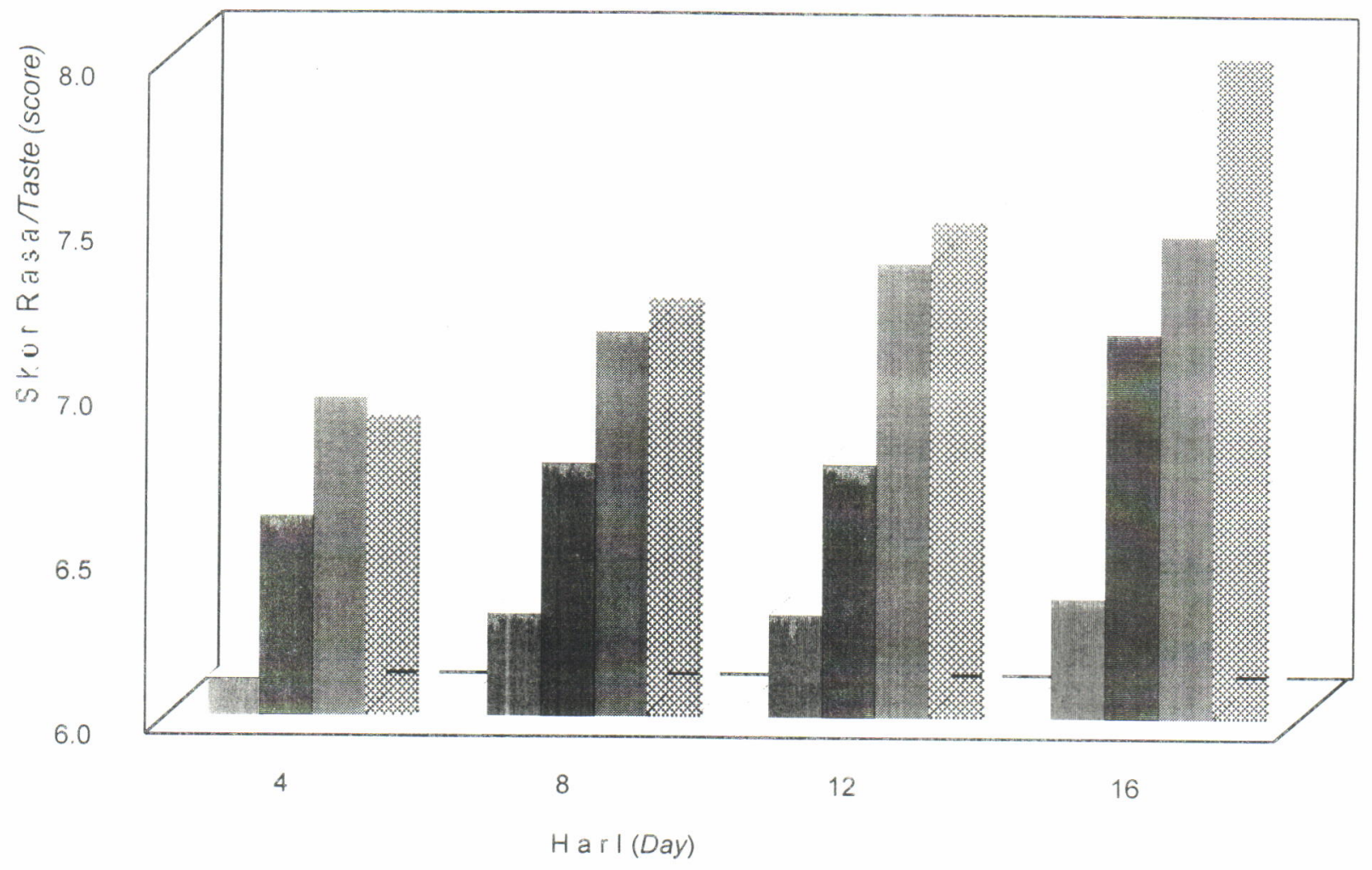

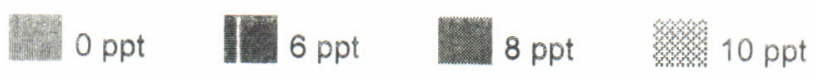

Gambar 3. Skor organoleptik pada rasa daging ikan mas

Figure 3. Organoleptic score of common carp meat taste

analisis asam amino yang berpengaruh terhadap cita terbentuk dari awal dimulainya penelitian sampai hari rasa menunjukkan asam amino esensial yang ke-16 adalah histidin dan prolin. Persentase asam

Tabel 3. Jenis asam amino (\%) pada ikan mas, sebelum dan pada akhir pemeliharaan

Table 3 Amino acid (\%) of common carp before and after culture period

\begin{tabular}{lcc}
\hline \multirow{2}{*}{ Asam amino (Amino acid) } & \multicolumn{2}{c}{ Kandungan (Content) (\%) } \\
\cline { 2 - 3 } & Awal (Begining) & Akhir (End) \\
\hline Glutamic acid & 1.47 & - \\
Serin & - & 0.96 \\
Glisin & 0.52 & - \\
Histidin & 1.11 & 1.33 \\
Arginin & 0.93 & 1.26 \\
Threonin & 0.44 & - \\
Alanin & - & 0.86 \\
Prolin & 0.93 & 1.33 \\
Tirosin & 2.84 & 2.54 \\
Valin & - & 0.88 \\
Metionin & - & 1.01 \\
Sistin & 1.87 & - \\
Isoleusin & 1.92 & - \\
Leusin & 1.03 & 0.51 \\
Phenil Alanin & - & 0.67 \\
Lisin & 0.71 & 1.3 \\
\hline
\end{tabular}


amino yang terbentuk menurut asal ikan terlihat pada Tabel 3

\section{KESIMPULANDAN SARAN}

1. Kualitas terbaik daging ikan mas asal kolam air deras dari segi tekstur dan rasa diperoleh pada hari ke-12 dengan salinitas 8 ppt.

2. Kualitas terbaik ikan asal keramba jaring apung diperoleh pada hari ke-16 dengan salinitas 10 ppt.

3. Kadar protein berkorelasi positif dengan kualitas daging ikan mas asal kolam air deras dan keramba jaring apung.

4. Asam amino esensial yang memberi rasa pada daging ikan di akhir penelitian adalah histidin dan prolin.

5. Penghitungan kelayakan ekonomi dikaitkan dengan upaya budi daya ikan mas di perairan tambak masih perlu dilakukan.

\section{DAFTARPUSTAKA}

Ardiwinata, R.O. 1981. Pemeliharaan Ikan Mas Jilid IV, Cetakan ke tiga. Penerbit sumur Bandung, Bandung. $140 \mathrm{pp}$

Anggawati, A.M., Yanti S., Wardana I., dan Sofyan I., 1991. Pemberokan (conditioning) ikan nila $\mathrm{m}$ e $\mathrm{r}$ a $\mathrm{h}$ dalam jaring apung di Teluk Banten. Bulletin Penelitian Perikanan No. 3. Puslitbang Perikanan, Jakarta. 135-141.

Boyd, C.E. dan Lichkoppler, F. 1979. Water Quality Management in Pond Fish Culture. $4^{\text {th }}$ printing. International Centre for Agriculture Experiment Station, Auburn. 359pp.
Ding,L.M., Yongging and Xianghua, L., 1989. Improvement of meat quality of grass carp, Ctenopharyngodon idellus (CUV.et Val.), p 148-152. In de Silva S.S. in: Fish Nutrition Research in Asia Proceeding of the Third Asian Fish Nutrition Network Meeting. Asian Fish Soc. Spec. Publ 4, 166 pp. Asian Fisheries Society, Manila Philippines

Halver, J.E. 1972. Fish Nutrition. Academic Press, New York. N.Y.713p

Lam, T.J. and Sharma, R. 1985. Effects of Salinity and Thiroxine on Larva survival, Growth and Development in the Carp Cyprinus carpio Aquaculture 44: 201-212

Lovell,R.T., \& L.A.Sackey, L.A. 1973. Absorption by channel catfish of earthymusty flavor compounds synthesized by culture of blue-green algae. Transaction of the American Fisheries Society. 102: 774-777.

National Research Council.1977. Nutrient Requirements of Warmwater Fishes. National Academy of Sciences, Washington D.C. p 71.

Schmidt, K. and Nielsen, 1988. Animal Physiology. Adaptation and environment. Cambridge University Press. Cambridge New York. New Ochelle, Melbourne, Sydney. 314pp.

Setijaningsih, L. 1999. Pengendalian bau lumpur pada daging ikan gurami. Warta Penelitian dan Pengembangan Pertanian. Badan Penelitian dan Pengembangan Pertanian. Vol 21 No 1. 1-2.

Soewarno, S.T. 1985. Penilaian Organoleptik untuk Industri Pangan dan Hasil Pertanian. Penerbit Batara Karya Aksara, Jakarta. 103 pp.

Tajerin, Mursidin, dan Baden M. 1997. Pengaruh kecepatan arus air dalam kolam terhadap tekstur daging ikan mas. Laporan Hasil Penelitian Balitkanwar. 


\title{
KOMPOSISI DAN ASPEK REPRODUKSI BEBERAPA SPESIES HASIL TANGKAPAN PUKAT CINCIN DI PERAIRAN BAGIAN SELATAN LAUT CINA SELATAN
}

\author{
Suherman Banon Atmaja'
}

\begin{abstract}
ABSTRAK
Pengumpulan data pada kegiatan penelitian sumber daya perikanan pelagis kecil di perairan Laut Cina Selatan telah dilaksanakan selama periode 1996 -1998. Data biologi reproduksi dan frekuensi panjang dikumpulkan dari hasil tangkapan kapal pukat cincin yang melakukan penangkapan komersial atas berbagai jenis ikan pelagis (terutama lima jenis ikan yang dominan, yaitu : Decapterus russelli, Decapterus macrosoma, Rastrelliger kanagurta, Amblygaster sirm dan Selar crumenophthalmus). Hasil analisis bobot contoh per basket memperlihatkan dominasi jenis ikan layang, yaitu D. russelli sebesar $58 \%$ dan D. marcosoma sebesar $17,8 \%$. Dengan taraf kepercayaan sebesar $95 \%$ nilai GSI pada kelompok ukuran ikan di atas $16 \mathrm{~cm}$ menunjukkan nilai GSI D. russelli berkisar antara 2,75 sampai dengan 3,15 , selanjutnya berturut-turut $D$. macrosoma $(2,97$ - 3,93), S. crumenophthalmus $(2,19-2,61)$, R. kanagurta $(3,11-3,91)$, dan A. sirm $(1,2-$ 2,37 ). Selang kepercayaan nilai GSI tersebut mencerminkan bahwa sangat jarang ikan dengan panjang lebih dari $16 \mathrm{~cm}$ yang matang gonad ditemukan dari hasil tangkapan pukat cincin. Secara keseluruhan perbandingan jenis kelamin antara jantan dan betina adalah seimbang. kecuali $D$. russelli, di mana ikan jantan lebih banyak daripada betina.
\end{abstract}

ABSTRACT: Composition and reproductive aspects of some species of purse seine catch in the southern part of the South China Sea. By: Suherman Banon Atmaja.

A serial data collection of research activities on small pelagic fisheries resources in the southern part of South China Sea was carried out during 1996 - 1998 periods. Biological data including reproductive aspects and length frequencies were collected from the catch of purse seiner, particularly of the five dominant species, i.e., D. russelli, D. macrosoma, R. kanagurta, A. sirm and $\mathbf{S}$. crumenophthalmus. From the results obtained it was found that the scads (Decapterus spp.) provided the major component of the small pelagic fish resources in southern part of South China Sea. This species group represented $80 \%$ of the catch, i.e., D. russelli (58\%) and D. macrosoma (17.8\%), respectively. Confidence limits (95\%) of GSI values showed that fish with length longer than $16 \mathrm{~cm}$ with ripe gonad in the samples were rarely found from the purse seiner catch. For each species, the sex ratio was 1:1 (male: female), except for D. russelli where the number of male in the sample was bigger than female.

KEYWORDS: $\quad$ biology, catch, purse seine, South China Sea

\section{PENDAHULUAN}

Perairan bagian selatan Laut Cina Selatan merupakan paparan benua dengan kedalaman ratarata $70 \mathrm{~m}$. Sekitar sepertiga luas perairan termasuk ke dalam perairan teritorial dan ZEE Indonesia. Dengan iklim tropis dan curah hujan yang tinggi, Laut Cina Selatan termasuk ekosistem dengan keanekaragaman jenis ikan yang tinggi. Sumber daya ikan pelagis kecil terdiri atas kelompok komunitas ikan "coastal species" (Sardinella spp., Rastrelliger brachysoma, Dussumeiria acuta, Selar spp.), "neritic species" (Decapterus russelli, Selar crumenophthalmus) dan "oceanic species" (Rastrelliger kanagurta, Decapterus macrosoma, Amblygaster sirm). Kelompok jenis ikan layang (Decapterus spp.) merupakan komponen utama di perairan ini, di mana dominasi jenis ikan tersebut terjadi pada daerah penangkapan yang dipengaruhi oleh massa air yang bersifat oseanik (Sujastani \& Amin, 1978; Sadhotomo et al., 1986; Yanagawa, 1995; Mertha \& Nurhakim, 1995). Hasil penelitian dengan akustik menunjukkan keberadaan dan kelimpahan ikan pelagis pada musim barat dan timur cenderung berbeda (FAO W/R, 1985). Stok ikan pelagis kecil di gugusan perairan Anambas diperkirakan sekitar 183.000 ton dan 150.000 ton di perairan Natuna (Badrudin, 1986). Venema (1997) in Menasveta (1997) melaporkan bahwa potensi sumber daya ikan pelagis kecil di perairan Laut Cina Selatan yang masuk wilayah Indonesia diperkirakan mencapai 504.000 ton dan yang baru dimanfaatkan sebesar 113.000 ton, belum termasuk hasil tangkapan pukat cincin yang berasal dari Thailand.

Pemanfaatan sumber daya ikan pelagis menjadi semakin intensif sejak beroperasinya armada pukat cincin yang berasal dari Tegal dan Pekalongan pada 


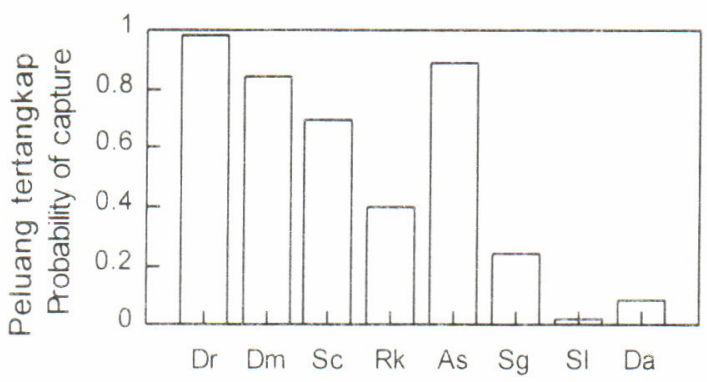

b

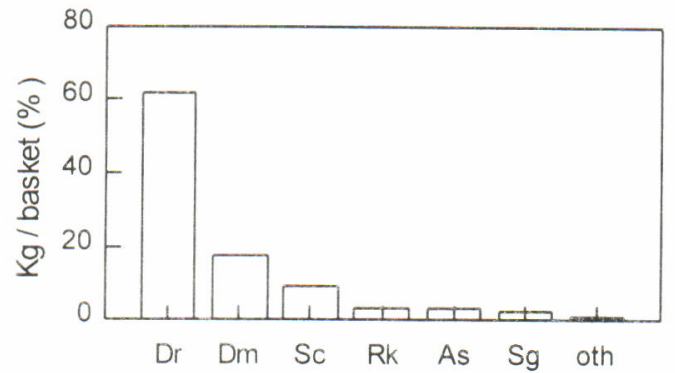

\footnotetext{
Gambar 1 a. Peluang tertangkap ikan pelagis oleh kapal pukat cincin

b. Komposisi hasil tangkapan dalam $\mathrm{kg} /$ basket $(\%)$.

(keterangan: Dr: D. russelli, Dm: D. macrosoma, Rk: $R$ kanagurta, Sc: S crumenophthaimus, As: A sirm, Sg: Sardinella spp., Sl: Selar spp., Da: Dussumeiria acuta, oth: others)

Figure $1 \quad$ a. Capture probability of pelagic fish by purse seiners

b. Catch composition in $\mathrm{kg} /$ basket (\%)

(Remarks: Dr: D. russelli, Dm: D. macrosoma, Rk: R. kanagurta,Sc: S. crumenophthalmus, As: A sirm, Sg: Sardinella spp., Sl: Selar spp., Da: Dussumeiria acuta, oth: others)
}

tahun 1983/1984 di perairan teritorial dan ZEE wilayah Indonesia. Sejak tahun 1987, alat tangkap pukat cincin berkembang di Pontianak dan meluas ke Pemangkat pada tahun 1990. Informasi mengenai aspek biologi jenis ikan yang dominan tertangkap di perairan wilayah Indonesia sangat terbatas, kecuali perikanan kembung ( $R$. kanagurta dan $R$. brachysoma) di perairan pantai Tanjung Satai yang dilaporkan oleh Sudjastani (1974a;b). Ikan layang (Decapterus spp.) sebagai komponen utama sumber daya ikan pelagis kecil belum tercatat dalam data statistik perikanan di Propinsi Kalimantan Barat dan Riau.

Tulisan ini merupakan upaya identifikasi tentang beberapa aspek sumber daya ikan pelagis yang berada di daerah operasi p enangkapan pukat cincin di bagian selatan Laut Cina Selatan, terutama lima jenis ikan pelagis kecil yang mendominasi hasil tangkapan.

\section{BAHAN DAN METODE}

Data yang dianalisis diperoleh dari hasil usaha penangkapan komersial dengan pukat cincin yang beroperasi di perairan Laut Cina Selatan teritorial Indonesia. Pengumpulan data dilakukan di Pelabuhan Perikanan Nusantara Pekalongan dan Perikanan Nusantara Pantai Pemangkat selama periode bulan Oktober 1996 - Maret 1998. Data yang dikumpulkan meliputi frekuensi panjang cagak (FL) bulanan dan aspek-aspek reproduksi.

Data frekuensi panjang ikan diperoleh melalui pengambilan contoh langsung dari palka yang dilakukan setiap hari pada kapal yang berbeda, secara acak berlapis menurut waktu dan daerah penangkapan. Contoh diambil sebanyak satu basket, kemudian disortir dan dihitung jumlahnya menurut jenis ikan. Contoh ikan yang diukur panjangnya sebanyak 50 ekor per basket sesuai dengan Boely et al. (1990) dan Potier \& Sadhotomo (1991). Bobot contoh ikan dihitung dengan menggunakan persamaan hubungan panjang bobot. Prosedur dan perhitungan bobot contoh ikan dilihat pada Lampiran 1. Bobot contoh ikan ini diaplikasikan untuk menduga komposisi hasil tangkapan per basket.

Data aspek reproduksi dikumpulkan pada tahun 1997 (Februari, April, Mei, Juni, dan Oktober) dan Februari 1998. Data yang dicatat meliputi: panjang cagak $(F L)$, boboikan, bobot gonad, tingkat kematangan gonad dan jenis kelamin. Kondisi gonad ikan betina pada kelompok FL>16 cm ditentukan secara kuantitatif dengan nilai Indeks Gonado Somatik (GSI) dan disajikan melalui sebaran nilai GSI. Metode diagram kotak garis (Box \& Whisker plot) digunakan untuk melihat penyebaran data nilai GSI tersebut. Diagram tersebut dibentuk dari ringkasan lima nilai angka, yaitu minimum (batas bawah), kuartil pertama, median, kuartil ke dua, dan maksimum (batas atas) (Turkey, 1977)

Perbandingan jenis kelamin ditentukan dari perbandingan jumlah jenis kelamin jantan dengan betina yang berasal dari contoh kelompok ukuran ikan yang secara visual telah dapat dibedakan jenis kelaminnya. Perbandingan jumlah jantan dan betina dilakukan melalui uji $\mathrm{X}^{2}$ sesuai dengan yang diharapkan secara hipotesis sama dengan 1:1

\section{HASIL DAN BAHASAN}

\section{Komposisi Hasil Tangkapan}

Berdasarkan pengambilan contoh langsung dari palka sebanyak 161 kali ulangan pada kapal yang 


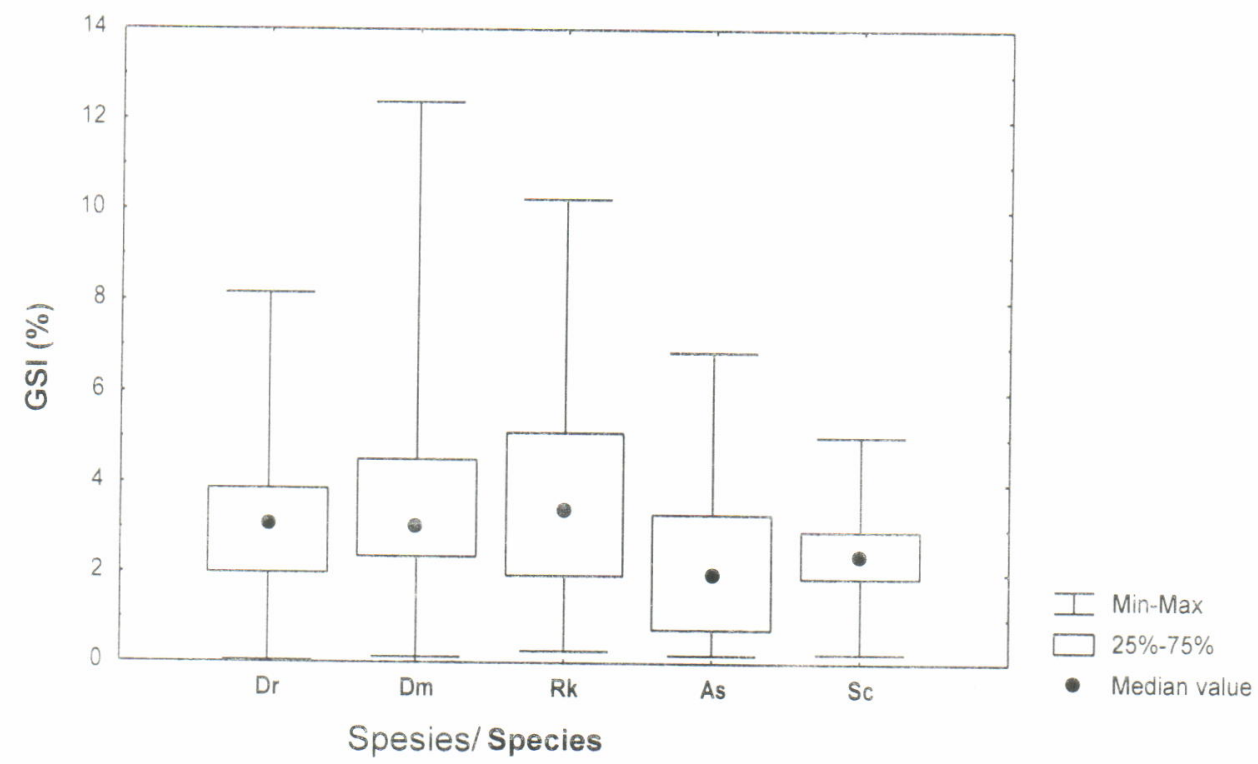

Gambar 2a. Sebaran nilai GSI kelompok ikan dewasa (keterangan: Dr: D. russelli, Dm: D. macrosoma, Rk: R. kanagurta, As: A. sirm, Sc: S. crumenophthalmus

Figure 2a. Distribution of GSI on adult fish (Remarks: Dr: D. russelli, Dm: D. macrosoma, Rk: R. kanagurta, As: A. sirm, Sc: S. crumenophthalmus

berbeda terlihat frekuensi kejadian individu jenis ikan pelagis di Laut Cina Selatan. Kelompok ikan layang (D. russelli) menempati urutan pertama, yaitu $D$. russelli $(0,98)$. Urutan selanjutnya adalah siro $(A$. sirm) $(0,89)$, layang deles $(D$. macrosoma) $(0,84)$, bentong (S. crumenophthalmus) $(0,70)$, banyar $(R$. kanagurta) $(0,40)$, juwi/tanjan (Sardinella spp.) $(0,28)$, japuh (Dussumeiria acuta) $(0,09)$ dan selar (Selarspp.) $(0,02)$ (Gambar 2a).

Persentase rata-rata bobot per basket, ikan layang (D. russelli ) mendominasi hasil tangkapan (60\%), kemudian berturut-turut layang deles (D. macrosoma) $(17,8 \%)$, bentong $(9,3 \%)$, banyar $(3,6 \%)$, siro $(3,7 \%)$, dan juwi/tanjan (2,8\%) (Gambar 1b). Ikan siro dan bentong kerapkali tertangkap oleh pukat cincin, namun dalam bobot lebih kecil dari ikan layang jenis $D$ russelli dan D. macrosoma. Hal ini menunjukkan bahwa bentuk gerombolan ikan siro dan bentong relatif lebih kecil dibandingkan dengan gerombolan ikan layang

Dibandingkan dengan hasil kegiatan pengambilan contoh yang dilakukan pada awal perluasan pukat cincin ke perairan Laut Cina Selatan tahun 1984/1985 di mana hampir seluruh kapal pukat cincin masih menggunakan rumpon sebagai alat bantu utama pengumpulan ikan, telah terjadi perubahan hasil tangkapan ikan layang, yaitu jenis ikan layang $D$ russelli meningkat dari 29\%-36\% menjadi 60\%,

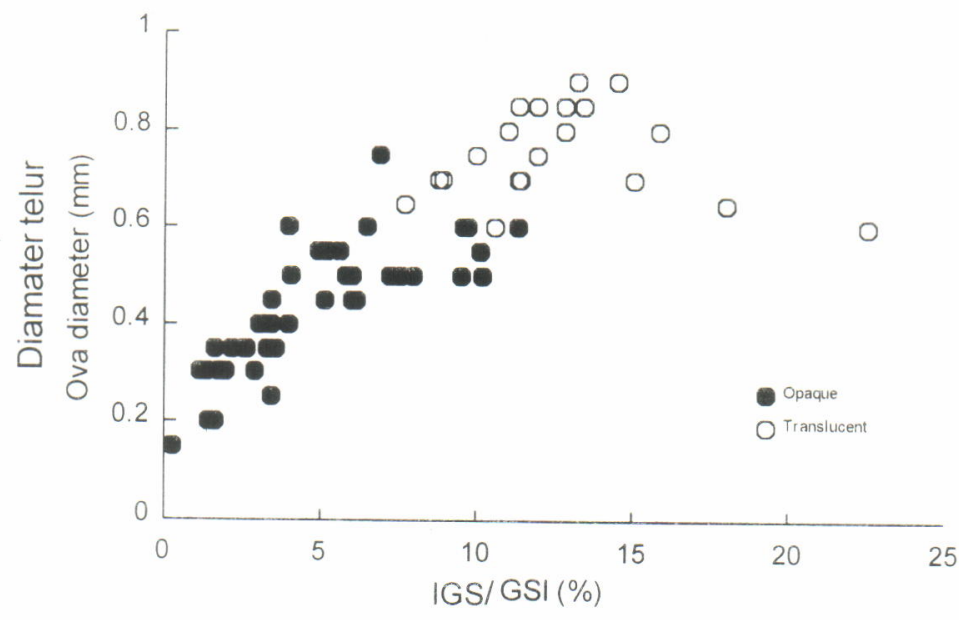

Gambar 2b. Ilustrasi rata-rata diameter telur ( $\mathrm{mm}$ ) dan IGS (\%)

Figure $2 b$. Illustration of average eggs diameter $(\mathrm{mm})$ and $\mathrm{GSI}(\%)$ 
Tabel 1. Perbandingan kelamin lima jenis ikan pelagis

Table 1. Sex ratio of the five species of small pelagic fish

\begin{tabular}{lcccc}
\hline \multicolumn{1}{c}{ Spesies (Species) } & \% Jenis (Female) & N & Chi square & Keterangan (Remaks) \\
\hline D. russeli & 43.49 & 538 & 9,108 & $\mathrm{~s}(\mathrm{p}=0.05)$ \\
D. macrosoma & 50.12 & 854 & 0.005 & $\mathrm{~ns}(\mathrm{p}=0.05)$ \\
R. kanagurta & 47.11 & 121 & 0.405 & $\mathrm{~ns}(\mathrm{p}=0.05)$ \\
A. sirm & 47.37 & 133 & 0.368 & $\mathrm{~ns}(\mathrm{p}=0.05)$ \\
S. crumenophthalmus & 48.04 & 281 & 0.597 & $\mathrm{~ns}(\mathrm{p}=0.05)$ \\
\hline
\end{tabular}

Keterangan (Remarks): $\mathrm{s}=$ nyata (significant), $\mathrm{ns}=$ tidak nyata (not significant)

sedangkan D. macrosoma relatif tetap (15-18\% menjadi 17,8 \%) (Sadhotomo et al., 1986; Suwarso et al., 1987). Penyebab perubahan tersebut antara lain diduga karena adanya perubahan taktik penangkapan dari menggunakan rumpon diganti dengan menggunakan cahaya dan perluasan daerah penangkapan yang semakin ke utara ( $P$. Midai, $P$. Serasan, dan P. Natuna).

\section{Perbandingan Jenis Kelamin}

Organ jenis kelamin ikan dapat dengan mudah dibedakan melalui pengamatan gonad. Organ jenis kelamin pada ikan jantan terdiri atas sepasang testis dan pada ikan betina berupa sepasang ovarium yang terletak pada rongga perut. Hasil uji $X^{2}$ menunjukkan bahwa perbandingan jenis kelamin jantan dan betina adalah seimbang $(p=0.05)$, kecuali $D$. russelli jenis kelamin jantan lebih banyak daripada jenis kelamin betina (Tabel 1)

Dibandingkan dengan hasil penelitian ikan pelagis kecil di Laut Jawa, D. macrosoma betina lebih banyak dari ikan jantan (Atmaja et al., 1995), sedangkan hasil penelitian yang diperoleh Widodo (1989;1991), perbandingan jenis kelamin ikan layang $D$. russelli dan D. macrosoma menunjukkan bahwa ikan jantan lebih banyak dari ikan betina. Perbandingan jenis kelamin ikan tidak selalu sama tergantung spesies dan perairannya. Pada $D$. russelli yang tertangkap di perairan Teluk Manila dan sekitarnya, ikan jantan lebih banyak daripada ikan betina, sedangkan di perairan Palawan ikan jantan dan betina adalah seimbang (Tiews et al., 1968).

\section{Sebaran Nilai GSI}

Sebaran nilai GSI (\%) pada kelompok panjang cagak $(F L)>16 \mathrm{~cm}$ memperlihatkan bahwa pemusatan nilai GSI hampir semua jenis ikan mengarah ke bawah, dengan median dan kuartir 3 ( $75 \%$ dari sebaran data nilai GSI) $<4 \%$, kecuali kuartir 3 nilai GSI R. kanagurta $>4 \%$ (Gambar 2a). Dengan taraf kepercayaan sebesar 95\%, nilai GSI berkisar antara 2,75 sampai dengan 3,15 untuk D. russelli. Selanjutnya berturut-turut $D$. macrosoma $(2,97-3,93)$, S. crumenophthalmus $(2,19-2,61), R$. kanagurta $(3,11-$ 3,91), dan (A. sirm) $(1,82-2,37)$. Sadhotomo (1998) melaporkan bahwa nilai GSI lebih besar dari $4 \%$ termasuk kriteria ovarium matang. Dari Gambar 2b dapat dilihat bahwa nilai GSI lebih kecil dari $4 \%$ mempunyai rata-rata diameter telur lebih kecil dari $0,4 \mathrm{~mm}$, sedangkan pada kriteria ovarium matang terdapat dua kelompok, yaitu rata-rata diameter telur masih buram (opaque) berkisar 0,50 - 0,75 mm dan telur yang jernih (translucent) rata-rata berdiameter 0,6-0,95 mm

Rendahnya nilai GSI merupakan fenomena alam, sehubungan dengan perilaku ikan bermigrasi menuju daerah pemijahan. Bal \& Rao (1984) menerangkan bahwa intensitas makan dari ikan pada kondisi matang telur (siap berpijah) pada umumnya menurun akibat sebagian besar ruang rongga perut terisi oleh ovarium. Intensitas makan yang tinggi terjadi setelah pemijahan. Dengan demikian, kelompok berukuran panjang cagak $16 \mathrm{~cm}$ dengan selang kepercayaan nilai GSI $95 \%$ tersebut berpeluang tertangkap dalam bentuk gerombolan.

Sebagian besar individu ikan di perairan tropis memijah sepanjang tahun dengan puncak musim sekali atau dua kali setahun (Erdman, 1976 dalam Saila, 1979). Aktivitas reproduksi di perairan tropis dibangkitkan oleh suhu dan salinitas yang spesifik dari kondisi musim (Weber, 1976 dalam Saila, 1979). Ikan pelagis di perairan Teluk Siam melangsungkan pemijahan sepanjang tahun, dengan puncak musim pemijahan berkisar antara bulan Januari sampai dengan bulan Maret dan antara bulan Mei sampai dengan bulan Agustus (Bhatiyasevi, 1997). Adanya individu ikan pada kelompok FL lebih besar dari 16 $\mathrm{cm}$ telah mencapai nilai maksimum lebih besar dari 4\% memberi suatu indikasi bahwa kelima jenis ikan ini melangsungkan pemijahan di perairan teritorial Indonesia. 


\section{KESIMPULAN DAN SARAN}

Dari uraian yang telah dikemukakan dapat disimpulkan sebagai berikut:

1. Perubahan komposisi hasil tangkapan di Laut Cina Selatan antara lain diduga karena adanya perubahan taktik penangkapan dari menggunakan rumpon diganti dengan menggunakan cahaya dan perluasan daerah penangkapan yang semakin ke utara (P. Midai, P. Serasan, dan P. Natuna)

2. Stok ikan yang tersedia di perairan lepas pantai bagian selatan Laut Cina Selatan untuk perikanan pukat cincin terdiri atas kelompok ikan layang $(D$. russelli dan $D$. macrosoma), bentong ( $S$. crumenophthalmus), banyar ( $R$. kanagurta), juwi/ tanjan (Sardinella spp.), siro (A. sirm), japuh ( $D$. acuta), dan selar (Selar spp.). Ikan layang merupakan komponen utama.

3. Hasil tangkapan pukat cincin didominasi oleh ikan dewasa yang reproduksinya tidak aktif. Ikan pada kondisi matang gonad sangat jarang ditemukan dari hasil tangkapan pukat cincin atau paling tidak ikan-ikan ini tidak memijah di daerah penangkapan pukat cincin. Pada selang kepercayaan sebesar 95\% dari nilai GSI tersebut dimungkinkan ikan dewasa tertangkap dalam bentuk gerombolan.

4. Penetapan spesifik daerah pemijahan dari hasil tangkapan pukat cincin masih sulit dilaksanakan. Penelitian khusus, seperti: sebaran larva, fase planktonik dan yuwana akan sangat bermanfaat.

\section{DAFTAR PUSTAKA}

Atmaja, S.B., B. Sadhotomo dan Suwarso. 1995. Reproduction of main small pelagic species in Java Sea. In:Potier and S. Nurhakim (Eds.): Biology, Dynamics and Exploitation of small pelagic in Java Sea (BIODYNEX). AARD/ORSTOM. 69-84

Badrudin, M. 1986. The small pelagic fish stock abundance in the surrounding waters of Anabas and Natuna Islands group of Riau Province. Jur. Pen. Per. Laut. 36:31-38.

Bal, D.V. and K. Virabhadra Rao. 1984. Marine Fisheries. Tata Mcgraw-Hill Pub. Com. Lim. New Delhi. 455 p.

Bayer, J.E. 1987. On length-weight relationships. Part I. Computing the mean weight of fish in a given length class. Fishbyte. ICLARM. Vol: 5(1):11-13.

Bhatiyasevi, U. 1997. Marine resources and fisheries in the exclusive economic zones of Thailand. In: Fishery Resources and State of Stocks Exploitation in the Waters of Gulf of Thailand, East Coast of Peninsular Malaysia and Andaman Sea. Training Department. SEAFDEC. $90 \mathrm{pp}$.

Boely, T.; M. Potier and S. Nurhakim, 1990. Study of the big purse seines fishery in the Java Sea. (VI. Sampling). Jur. Pen. Per. Laut. 56:1-12.
FAO WIR. 1985. Report on 1982-1983 Acoustic Survey of Pelagic Fish Resource around Natuna and Jemaja Islands, South China Sea. FAO. Rome. 82 pp.

Mertha, I.G.S. dan S. Nurhakim, 1995. The development of marine fishery in the South China Sea area of Indonesia. Country Status Report. The Second Regional Workshop on Shared Stocks in the South China Sea Area. Kuala Terengganu Malaysia 18-20 July 1995. SEAFDEC/MFRDMDMS/ 95/CR 6. 91-98.

Menasveta, D. 1997. Fisheries management frameworks of the countries bordering the South China Sea. FAO Regional Office for Asia and the Pacific, Bangkok. Rap. Publication 1997/33.151 pp.

Nurhakim, S. 1995. Population Dynamics of Ikan Banyar (Rastrelliger kanagurta). In:Potier and S. Nurhakim (Eds.) Biodynex: Biology, Dynamics and Exploitation of Small Pelagic in Java Sea. AARD/ORSTOM. p. 109124.

Potier, M; T. Boely; S. Nurhakim; and S.B. Atmaja, 1988 Study of the big purse seines fishery in the Java Sea (IV. Catch). Jur. Pen. Per. Laut. 48:19-46.

Potier, M. and B. Sadhotomo, 1991. Sampling Training Sci. and Tech. Doc. No. 4. Java Sea Pelagic Fishery Assessment Project. $10 \mathrm{pp}$

Sadhotomo, B.; S. Nurhakim dan S.B. Atmaja. 1986 Perkembangan komposisi hasil tangkapan dan laju tangkap pukat cincin di Laut Jawa. Jur. Pen. Per. Laut 35:101-109.

Sadhotomo, B. 1998. Bioécologie des Principales Espèces Pélagiques Exploitées en mer de Java. Phd Thesis, Université de Montpellier II, 364 pp

Saila, S.B. 1979. Some environmental considerations for stock assessment of small scale fisheries. In: Saila, S.B and P.M. Roedel (Eds.): Stock Assessment for Tropical Small Scale Fisheries. Inter. Center for Marine Resource Develop. University of Rhode Island. p. 60-69

Sujastani, T. dan E.M. Amin 1978. Kemungkinan pengembangan dan modernisasi perikanan skala kecil atau perikanan rakyat di perairan Laut Cina Selatan yang termasuk kawasan Kabupaten Kepulauan Riau. Simposium Modernisasi Perikanan Rakyat. LPPL. Litbang Pertanian. 26 pp.

Sujastani, T. 1974a. The species of Rastrelliger in the Java Sea, their taxonomy and morphometry (Perciformes, Scombridae). Mar. Res. Indonesia, 16:1-29

Sujastani, T. 1974b. Dinamika populasi ikan kembung di Laut Jawa. LPPL. 1:30-64.

Suwarso, S.B Atmaja dan M. Wahyono. 1987 Perkembangan komposisi ikan layang (Decapterus spp.) dari hasil tangkapan pukat cincin menurut daerah penangkapan di Laut Jawa. Jur. Pen. Per. Laut. 38:35-58

Suwarso, 1993. Length-weight relationships of the main pelagic fishes of Java Sea. ALA/INS/87/17. Scien, and Tech. Doc. 10. 22 pp

Tiews, K.; I.A. Ronquillo and P. Caces-Borja. 1968. On the biology of round scads (Decapterus Bleeker) in the Phillippines waters. Proc. IPFC. 13 (II):82-106. 
Tukey,J.W.,1977. Exploratory Data Analysis. AddisonWesley, Reading, Massachusetts. 531 pp.

Widodo. J. 1989. Reproductive biology and harvesting strategy of Indian scad Decapterus russelli (Ruppel 1830) (Pisces: Carangidae of the Java Sea). Jur. Pen. Per. Laut: 53:89-96.

1991. Maturity and spawning of shortfin scad (Decapterus macrosoma, Carangidae) of the Java Sea. Asian Fish. Sci. 4:245-252
Wyrthi. K. 1961. Physical oceanography of the southeast Asian Water. Naga Rep. 2:1-195.

Yanagawa, H. 1995. Status on fisheries exploitation and potential yield of round scads and mackerel in the region. The Second Regional Workshop on Shared Stocks in the South China Sea Area. Kuala Terengganu Malaysia 18 - 20 July 1995. SEAFDEC. MFRDMD RM/2. 141-163. 
Lampiran 1.Skema pengambilan contoh hasil tangkapan pukat cincin di TPI Pekalongan dan Pemangkat, perhitungan bobot contoh ikan.

Appendix 1.Sampling scheme for purse seine catch in landing place of Pekalongan and Pemangkat and calculation of sample weight

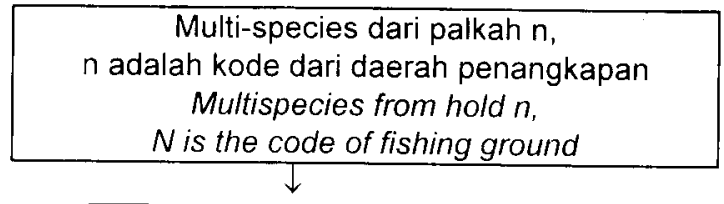

Satu keranjang sampel $( \pm 30 \mathrm{~kg})$

Sampling one basket $( \pm 30 \mathrm{~kg})$

Species pelagis kecil: Sin; jumlah ikan menurut species (i) pada daerah penangkapan (n)

Sincll pelagics species: Sin: number fish by species ( $i$ ) in fishing ground $(n)$

\begin{tabular}{|c|c|c|c|c|c|c|c|}
\hline $\mathrm{s} 1 \mathrm{n}$ & $\mathrm{s} 2 \mathrm{n}$ & $\mathrm{s} 3 \mathrm{n}$ & $\mathrm{s} 4 \mathrm{n}$ & $\mathrm{s} 5 \mathrm{n}$ & $\ldots$ & $\ldots$ & $\mathrm{s} 12 \mathrm{n}$ \\
\hline
\end{tabular}

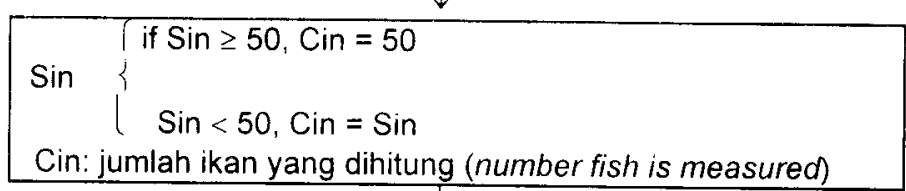

Cin: jumlah ikan yang dihitung (number fish is measured)

\begin{tabular}{|c|c|}
\hline \multicolumn{2}{|c|}{$\downarrow$ Frequency } \\
\hline 5.0 & fink \\
\hline 5.5 & \\
\hline$\ldots$ & \\
\hline 26 & \\
\hline sum & Cin \\
\hline
\end{tabular}

Sample dikumpulkan dari masing-masing satu basket sample: $\operatorname{Rfn}=\operatorname{Sin} /$ Cin Raising to one basket each sample: $\mathrm{Rfn}=\mathrm{Sin} / \mathrm{Cin}$

\begin{tabular}{|c|c|}
\hline$F L(\mathrm{~cm})$ & Frequency \\
\hline 5.0 & fik ${ }^{\star}$ Rfin \\
\hline 5.5 & \\
\hline$\ldots$ & \\
\hline 26 & Sin \\
\hline sum & \\
\hline
\end{tabular}

Perhitungan bobot sample

Hubungan panjang-bobot (Suwarso, 1993) dan persamaan Bayer (1987) :mik*.

Sample weight estimation through

Length- weight relationships (Suwarso, 1993) and Bayer formula (1987) : wik $^{*}$

\begin{tabular}{|c|c|c|}
\hline FL (cm) & Frequency & weight of sample \\
\hline 5.0 & fik ${ }^{*}$ Rfin & (fik *Rfin) ${ }^{\star}$ min \\
\hline 5.5 & & \\
\hline$\ldots$ & & \\
\hline 26 & Sin & ws $=\sum$ (fik *Rfin) ${ }^{*}$ min \\
\hline Sum & & \\
\hline
\end{tabular}

